\title{
Pendampingan Akuntansi Dan Keuangan BUMDes Sedahan Jaya Kecamatan Sukadana Kabupaten Kayong Utara
}

\author{
Risal $^{1}$, Renny Wulandari ${ }^{2}$, dan Jaurino ${ }^{3}$ \\ Universitas Panca Bakti, Pontianak 1,2,3 \\ risal@upb.ac.id ${ }^{1}$, rennywulandari@upb.ac.id², jaurino@upb.ac.id ${ }^{3}$
}

\begin{abstract}
Sedahan Jaya Village is one of the village that has established BUMDes but has not prepared any kind of financial reports properly based on applicable accounting standards. Bookkeeping activity is done every time a transaction occurs, but only limited between recording cash in and cash out without regarding to accounting principles. Because of the BUMDes treasurer does not have any background in accounting education and there is never held any kind of training related to the preparation of financial reports for BUMDes managers. This condition is increased the complexity of the problems faced by partners. The purpose of this activity is to provide knowledge and understanding in preparing financial reports, so that there is a need for knowledge transfer through the holding of seminars and training. The implementation method in this activity is by education approach. The educational approach is to provide knowledge and understanding of BUMDes management which is manifested in seminar activities and to held accounting training related to the preparation of BUMDes financial statements. The results of this activity is seminars and training activities for BUMDes managers about recording process in each transaction based on the accounting rules.
\end{abstract}

Keywords: BUMDes; Accounting Process; Financial Statements

\begin{abstract}
Abstrak
Desa Sedahan Jaya adalah salah satu desa yang telah mendirikan BUMDes. BUMDes Sedahan Jaya yang menjadi mitra belum melakukan penyusunan laporan keuangan dengan baik dan belum sesuai dengan standar akuntansi yang berlaku. Pembukuan yang dilakukan setiap terjadi transaksi, hanya sebatas mencatat kas masuk dan kas keluar tanpa memperhatikan kaidah akuntansi. Hal tersebut disebabkan karena bendahara BUMDes tidak memiliki latar belakang pendidikan akuntansi dan belum pernah diadakan pelatihan berkaitan dengan penyusunan laporan keuangan kepada para pengelola BUMDes sehingga menambah kompleksitas dari permasalahan yang dihadapi oleh mitra. Tujuan dari kegiatan ini adalah untuk memberikan pengetahuan dan pemahaman dalam menyusun laporan keuangan, sehingga dibutuhkan adanya transfer knowledge melalui penyelenggaraan seminar dan pelatihan. Metode pelaksanaa pada kegiatan PKM ini adalah dengan pendekatan pendidikan. Pendekatan pendidikan yang dimaksud adalah dengan memberikan pengetahuan dan pemahaman mengenai pengelolaan BUMDes yang diwujudkan pada kegiatan seminar serta menyelenggarakan kegiatan pelatihan akuntansi yang berkaitan dengan penyusunan laporan keuangan BUMDes. Hasil dari kegiatan pengabdian kepada masyarakat yaitu dengan adanya kegiatan seminar dan pelatihan ini pengelola BUMDes dapat membukukan setiap transaksinya ke dalam laporan keuangan yang sesuai dengan kaidah akuntansi.
\end{abstract}

Kata Kunci: BUMDes; Proses Akuntansi; Laporan Keuangan 


\section{Pendahuluan}

Desa merupakan suatu kesatuan masyarakat berdasarkan adat dan hukum adat yang menetap dalam suatu wilayah yang tertentu batas-batasannya, memiliki ikatan lahir dan batin yang sangat kuat, baik karena seketurunan maupun karena samasama memiliki kepentingan politik, ekonomi, sosial, dan keamanan; memiliki susunan pengurus yang dipilih bersama; memiliki kekayaan dalam jumlah tertentu dan berhak menyelenggarakan urusan rumah tangga sendiri. Di Indonesia, peraturan yang berkaitan dengan desa diatur di dalam Undang-undang Nomor 6 Tahun 2014 tentang Desa. Pasal 4 pada undang-undang tersebut menyebutkan ada 9 (sembilan) tujuan pengaturan desa, salah satunya yang berbunyi "mendorong prakarsa, gerakan, dan partisipasi masyarakat desa untuk pembangunan potensi dan aset desa guna kesejahteraan bersama". Tujuan inilah yang mendorong dilaksanakannya program Badan Usaha Milik Desa (Bumdes) di Indonesia.

Desa Sedahan Jaya adalah salah satu desa yang terletak di kecamatan Sukadana Kabupaten Kayong Utara. Luas desa Sedahan Jaya tertinggi kedua setelah desa Sejahtera, di mana luasnya mencapai $121,60 \mathrm{~km}^{2}$ dengan jumlah penduduk sebanyak 2.338 jiwa. Desa Sedahan Jaya memiliki potensi alam yang sangat baik, seperti panorama alam yang indah, hamparan persawahan masyarakat yang luas, perkebunan, keanekaragaman budaya dan etniknya serta kawasan hutan lindung dan pegunungan yang masih alami (Purnama, Iskandar, \& Dirhamsyah, 2019). Desa Sedahan Jaya Kecamatan Sukadana Kabupaten Kayong Utara memiliki jarak tempuh sekitar $313,78 \mathrm{~km}$ dari Kota Pontianak. Alat transportasi yang dipakai dari Kota Pontianak menuju ke Kecamatan Sukadana dapat menggunakan speed boat dan dilanjutkan dengan kendaraan roda empat atau roda dua menuju Desa Sedahan Jaya. Selain itu, bisa menggunakan pesawat terbang menuju Kabupaten Ketapang dan dilanjutkan ke Kabupaten Kayong Utara menggunakan kendaraan roda empat atau roda dua.

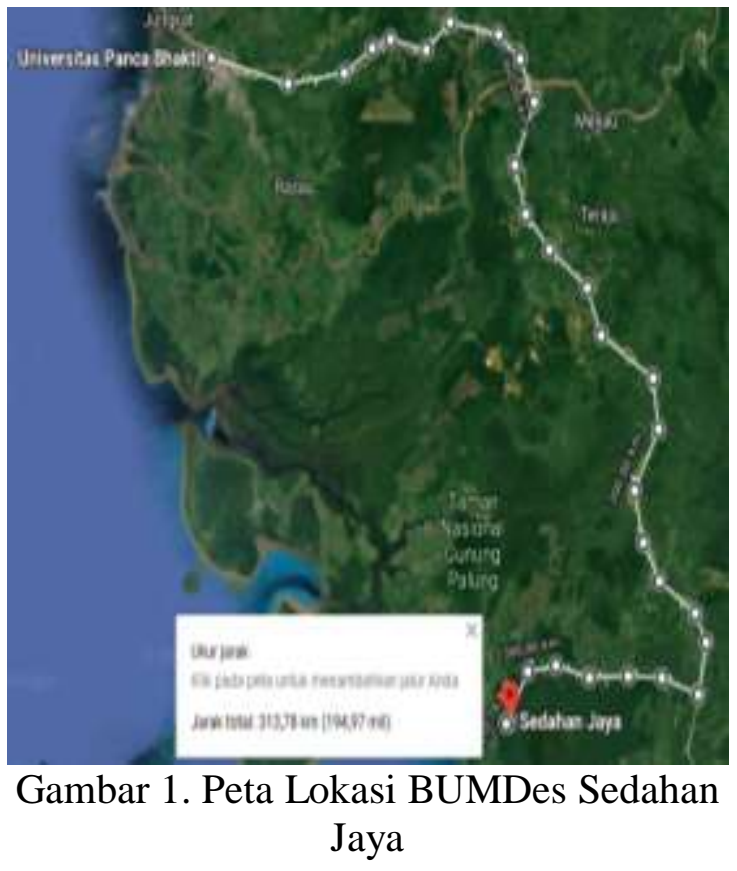

Melalui BUMDes diharapkan antar lembaga yang ada di masyarakat saling bersinergi untuk lebih maksimal menciptakan kesejahteraan masyarakat yang setara (Zulkarnaen, 2016). Upaya yang dilakukan oleh pemerintah desa dengan memperkenalkan atau mempromosikan potensi yang dimiliki desa Sedahan Jaya melalui berbagai media, cetak maupun secara daring. Kepala Desa Sedahan Jaya mengungkapakan bahwa desa Sedahan Jaya ke depannya akan berkembang menjadi desa wisata yang nantinya masyarakat juga dapat merasakan kontribusi dari keberadaan desa wisata yang dicanangkan (Norita, Zal, Ridwan, \& Evy, 2018). Tingginya animo masyarakat dibuktikan dengan meningkatnya kunjungan wisatawan, baik lokal mapun mancanegara.

Agar dapat mewadahi program desa wisata tersebut upaya selanjutnya yang dilakukan adalah mendirikan Badan Usaha Milik Desa (BUMDes) dengan nama BUMDes Sedahan Jaya. Badan Usaha Milik Desa (BUMDes) adalah lembaga usaha desa yang dikelola oleh masyarakat 
dan pemerintah desa dalam upaya memperkuat perekonomian desa dan dibentuk berdasarkan kebutuhan dan potensi desa. Keberadaan BUMDes membawa perubahan yang signifikan di bidang ekonomi dan juga sosial. Pergeseran nilai sosial dan juga perubahan pola interaksi antar warga akan terjadi (Anggraeni, 2016).

Pendirian BUMDes didasarkan pada kebutuhan dan potensi desa, sebagai upaya peningkatan kesejahteraan masyarakat. Berkenaan dengan perencanaan dan pendiriannya, BUMDes dibangun atas prakarsa (inisiasi) masyarakat, serta mendasarkan pada prinsip-prinsip kooperatif, partisipatif, transparansi, emansipatif, akuntabel, dan sustainable dengan mekanisme member-base dan self-help (Hidayat et al., 2018). Oleh karena itu, perlu upaya serius untuk menjadikan pengelolaan badan usaha tersebut dapat berjalan secara efektif, efisien, profesional dan mandiri.

BUMDes merupakan unit usaha yang telah lama menjadi program pemerintah pusat, namun seakan-akan baru dikenal di masa sekarang. Sosialisasi tentang BUMDes harus secara rutin dilakukan untuk memperkenalkan kepada seluruh warga negara Indonesia terutama untuk wilayah yang jauh dari ibukota negara maupun ibukota provinsi. Akses informasi yang terbatas karena kondisi geografis dari wilayah Indonesia menjadi kendala sehingga berdampak pada minimnya informasi yang diperoleh mengenai BUMDes.

Kendala kualitas Sumber Daya Manusia (SDM) juga menjadi agenda yang menghambat perkembangan BUMDes. Tingkat pendidikan sebagian kepala desa dan para perangkat desa adalah salah satunya. Kualitas SDM sangat mempengaruhi kemampuan seorang kepala desa untuk merumuskan kebijakan ekonomi bagi desanya (Kusmayadi, Firmansyah, \& Rahman, 2019).

Fakta lain dalam pengelolaan BUMDes berkaitan dengan permasalahan yang dihadapi oleh mitra yaitu BUMDes
Sedahan Jaya belum melakukan penyusunan laporan keuangan secara baik dan belum sesuai dengan standar akuntansi yang berlaku. Pembukuan yang dilakukan setiap terjadi transaksi, hanya sebatas mencatat kas masuk dan kas keluar tanpa memperhatikan kaidah akuntansi. Hal tersebut disebabkan karena bendahara BUMDes belum mengetahui dan memahami proses akuntansi beserta standar akuntansi yang digunakan. Akuntansi pada dasarnya merupakan proses pengidentifikasian, pengesahan, pengukuran, pengakuan, pengklarifikasian, pengga-bungan, peringkasan dan penyajian data keuangan dasar (bahan olah akuntansi) yang terjadi dari kejadian-kejadian, transaksi-transaksi atau kegiatan operasi suatu unit organisasi dengan cara tertentu untuk menghasilkan informasi yang relevan bagi pihak yang berkepentingan (Suwardjono, 2014).

Penyusunan laporan keuangan pada setiap entitas perlu dilaksanakan, tidak terkecuali pada BUMDes. Laporan keuangan menjadi gambaran penting di dalam melihat posisi keuangan dan kinerja keuangan. Laporan keuangan adalah suatu penyajian terstruktur dari posisi keuangan dan kinerja keuangan suatu entitas. Tujuan dari laporan keuangan adalah untuk memberikan informasi mengenai posisi keuangan, kinerja keuangan dan arus kas entitas yang bermanfaat bagi sebagian besar pengguna laporan keuangan dalam pembuatan keputusan ekonomik (IAI, 2018). Sama halnya dalam menyusun laporan keuangan BUMDes, pengelola BUMDes harus mencatat semua aktivitas usaha yang telah terjadi dan membukukannya ke dalam laporan keuangan. Laporan keuangan yang tersusun nantinya juga akan digunakan oleh pengelola BUMDes dalam pengambilan keputusan ekonomi.

Dari hasil wawancara yang dilakukan kepada kepala desa Sedahan Jaya beserta ketua BUMDes, diketahui bahwa warga yang menjadi bendahara BUMDes tidak memiliki latar belakang pendidikan akuntansi serta tidak mampu mengope- 
rasikan laptop yang menjadi inventaris dalam mendukung pembukuan BUMDes, sehingga tugas bendahara dikerjakan oleh bagian humas. Dampak dari pengalihan tugas tersebut membuat bagian humas terbebani dengan tugas yang bukan menjadi tanggungjawabnya dan berakibat pada tidak selesainya pembukuan BUMDes. Hal yang sama juga terjadi pada BUMDes di Kabupaten Jepara, dimana masih banyak pengurus BUMDes yang rangkap jabatan dengan lembaga lainnya, sehingga pengurus lebih fokus pada pekerjaan utamanya daripada fokus ke BUMDes (Agunggunanto, Arianti, Kushartono, \& Darwanto, 2016)

Di samping itu pula, pengelola BUMDes memiliki tingkat pendidikan setara dengan SMA bahkan masih ada yang lulusan sampai SMP saja dan juga belum pernah diadakan pelatihan berkaitan dengan penyusunan laporan keuangan kepada para pengelola BUMDes sehingga menambah kompleksitas dari permasalahan yang dihadapi oleh mitra.

Sebenarnya permasalahan seperti ini pernah dihadapi oleh BUMDes Putra Subagyo yang terletak di Desa Miagan, Kecamatan Mojoagung, Jombang, di mana para pengurus BUMDes masih kesulitan dalam mencatat transaksi dan menyusun laporan keuangan dengan benar yang sesuai dengan standar akuntansi. Dari hasil kegiatan PkM yang dilakukan, pengurus bisa melakukan pencatatan transaksi hingga penyusunan laporan keuangan setiap bulan, yang sesuai dengan standar akuntansi untuk perusahaan jasa (Mutiarni, Zuhroh, \& Utomo, 2018).

Berdasarkan paparan di atas, maka dibutuhkan adanya penyelenggaraan seminar pengelolaan BUMDes dan pelatihan di bidang akuntansi berkaitan dengan proses penyusunan laporan keuangan. Pelatihan akuntansi akan memberikan pengetahuan dan pemahaman secara praktik didalam menyusun laporan keuangan BUMDes dan meningkatkan kemampuan dari para pengelola BUMDes khususnya bendahara, sehingga mampu menghasilkan laporan keuangan yang sesuai dengan kaidah akuntansi yang berguna untuk pengambilan keputusan serta sebagai bentuk pertanggungjawaban pengelola kepada pemerintah desa maupun masyarakat. Target luaran pada kegiatan ini adalah adanya peningkatan pengetahuan mengenai pengelolaan BUMDes kepada Pemerintah Desa dan pengelola BUMDes, meningkatkan kompetensi serta pemahaman dari pengelola BUMDes didalam menyusun laporan keuangan BUMDes secara mandiri, terselenggaranya administrasi keuangan BUMDes yang sesuai kaidah akuntansi secara berkelanjutan dan menghasilkan model laporan keuangan BUMDes yang berbasis komputerisasi.

\section{Pelaksanaan Dan Metode}

Metode yang diterapkan pada kegiatan PkM ini tampak pada gambar berikut ini.

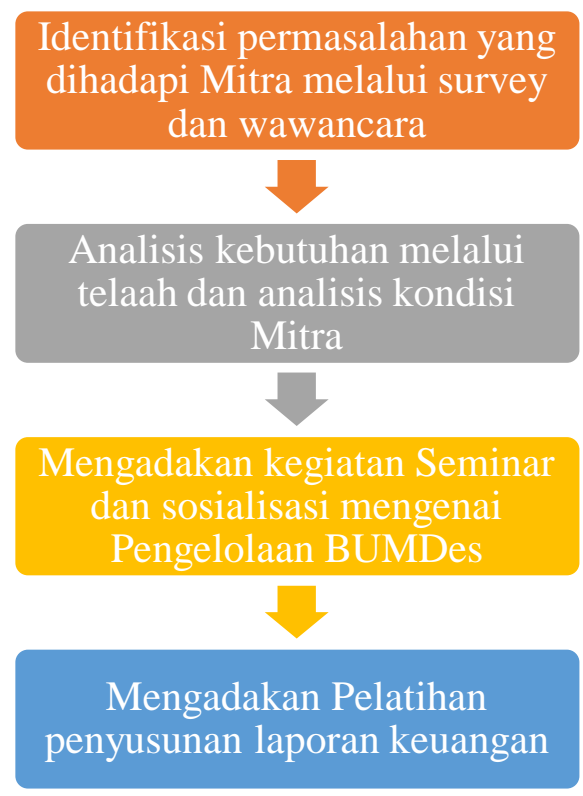

Gambar 2. Metode Pelaksanaan Kegiatan

Kegiatan Pengabdian Kepada Masyarakat ini dilaksanakan di Desa Sedahan Jaya, Kecamatan Sukadana, Kabupaten Kayong Utara, Kalimantan Barat. Metode yang digunakan pada kegiatan ini dengan pendekatan pendi- 
dikan. Pendekatan pendidikan yang dimaksud adalah dengan memberikan pengetahuan dan pemahaman mengenai pengelolaan BUMDes dengan metode ceramah yang diwujudkan pada kegiatan seminar serta menyelenggarakan kegiatan pelatihan akuntansi yang berkaitan dengan penyusunan laporan keuangan BUMDes. Pada kegiatan seminar mengenai pengelolaan BUMDes yang akan menjadi peserta adalah dari pihak pemerintah desa dan para pengelola BUMDes. Sedangkan kegiatan pelatihan penyusunan laporan keuangan akan diikuti oleh seluruh pengelola BUMDes. Partisipasi mitra sangat dibutuhkan agar kegiatan dapat terselenggara dengan baik. Bentuk partisipasi dari mitra diwujudkan dengan penyediaan tempat, fasilitas pendukung seperti proyektor, mic dan lain sebagainya, serta dukungan penuh dari pemerintah desa dan pengelola BUMDes dalam kegiatan yang dilaksanakan. Adapun rencana kegiatan untuk PkM ini adalah sebagai berikut.

Tabel 1. Jadwal Kegiatan

\begin{tabular}{|c|c|c|c|c|c|c|}
\hline \multirow{2}{*}{ No. } & \multirow{2}{*}{ Jenis Kegiatan } & \multicolumn{5}{|c|}{ Bulan Ke- } \\
\hline & & 1 & 2 & 3 & 4 & 5 \\
\hline \multirow[t]{5}{*}{1} & Tahap Persiapan & $\mathrm{X}$ & & & & \\
\hline & $\begin{array}{l}\text { Survei dan } \\
\text { sosialisasi }\end{array}$ & $\mathrm{X}$ & & & & \\
\hline & $\begin{array}{l}\text { Wawancara dan } \\
\text { diskusi }\end{array}$ & $\mathrm{X}$ & & & & \\
\hline & $\begin{array}{l}\text { Penyusunan jadwal } \\
\text { pelatihan dan } \\
\text { program kegiatan }\end{array}$ & $X$ & & & & \\
\hline & $\begin{array}{l}\text { Persiapan tempat, } \\
\text { alat dan fasilitas } \\
\text { penunjang }\end{array}$ & $X$ & & & & \\
\hline \multirow[t]{4}{*}{2} & $\begin{array}{l}\text { Tahap Pelaksanaan } \\
\text { Kegiatan }\end{array}$ & & $\mathrm{X}$ & & & \\
\hline & $\begin{array}{l}\text { Pelaksanaan } \\
\text { kegiatan seminar }\end{array}$ & & $\mathrm{X}$ & & & \\
\hline & $\begin{array}{l}\text { Pelaksanaan } \\
\text { kegiatan pelatihan }\end{array}$ & & $\mathrm{X}$ & & & \\
\hline & $\begin{array}{l}\text { Pembimbingan } \\
\text { lebih lanjut }\end{array}$ & & $\mathrm{X}$ & & & \\
\hline 3 & Tahap Evaluasi & & & $\mathrm{X}$ & & \\
\hline 4 & $\begin{array}{l}\text { Penyusunan } \\
\text { Laporan }\end{array}$ & & & $X$ & $\mathrm{X}$ & \\
\hline 5 & $\begin{array}{l}\text { Pengiriman } \\
\text { Laporan }\end{array}$ & & & & $\mathrm{X}$ & \\
\hline 6 & Publikasi Artikel & & & & & $\mathrm{X}$ \\
\hline
\end{tabular}

\section{Hasil dan Pembahasan}

Desa Sedahan Jaya adalah salah satu desa yang terletak di Kecamatan Sukadana Kabupaten Kayong Utara. Desa Sedahan Jaya memiliki panorama alam yang indah, sehingga banyak dikunjungi oleh wisatawan baik dalam maupun luar negeri. Desa ini memiliki BUMDes yang bernama BUMDes Sedahan Jaya yang mengelola usaha di bidang jasa pariwisata. Permasalahan yang dihadapi oleh BUMDes Sedahan Jaya adalah belum terlaksananya penyusunan laporan keuangan yang baik pada usaha yang diajalankan. Oleh karena itu, tim PKM berkesempatan untuk berbagi pengetahuan melalui penyelenggaraan seminar dan pelatihan berkaitan dengan pengelolaan dan penyusunan laporan keuangan BUMDes.

\section{Tahap Persiapan}

Pada tahap persiapan, tim $\mathrm{PkM}$ telah melaksanakan hal sebagai berikut:

1. Melakukan observasi dan sosialisasi kepada pemerintah desa serta para pengelola BUMDes Sedahan Jaya berkaitan dengan kegiatan yang dilaksanakan.

2. Melakukan wawancara dan diskusi dengan kepala desa dan para pengelola BUMDes mengenai potensi yang ada di Desa Sedahan Jaya.

3. Menyusun program kegiatan yang akan dilaksanakan.

\section{Tahap Pelaksanaan}

Kegiatan PkM tahun 2019 dilaksanakan di Kecamatan Sukadana Kabupaten Kayong Utara, tepatnya di Kantor Desa Sedahan Jaya. Kegiatan ini dilaksanakan pada tanggal 4 s.d 6 Agustus 2019 yang dihadiri oleh unsur pemerintah desa dan para pengelola BUMDes Sedahan Jaya. Pada tahap pelaksanaan, kegiatan yang diselenggarakan meliputi:

\section{Kegiatan Seminar Pengelolaan BUMDes}

Kegiatan seminar dilaksanakan pada tanggal 4 Agustus 2019 yang dihadiri 
oleh pihak pemerintah desa termasuk Bapak Nazanadira selaku Kepala Desa Sedahan Jaya dan pengelola BUMDes Sedahan Jaya. Adapun materi yang disampaikan berkaitan dengan "Pengelolaan BUMDes dan Adimistrasi Pelaporan Keuangan BUMDes" meliputi:

- Apa itu BUMDes???

- BUMDes sebagai Pilar Demokrasi Ekonomi.

- Menggerakkan dan Menata Potensi Ekonomi Desa Melalui BUMDes.

- Prinsip Pengelolaan BUMDes.

- Aktivitas Pendirian BUMDes.

- Manfaat Ekonomi Berdirinya BUMDes.

- Potensi dan Manfaat Ekonomi BUMDes.

- Analisis SWOT.

Kegiatan seminar yang dilaksanakan oleh tim PkM berjalan dengan lancar dan para peserta mengikuti dengan penuh semangat dan mereka merasa seminar yang terlaksana sangat bermanfaat untuk kemajuan BUMDes di masa mendatang.

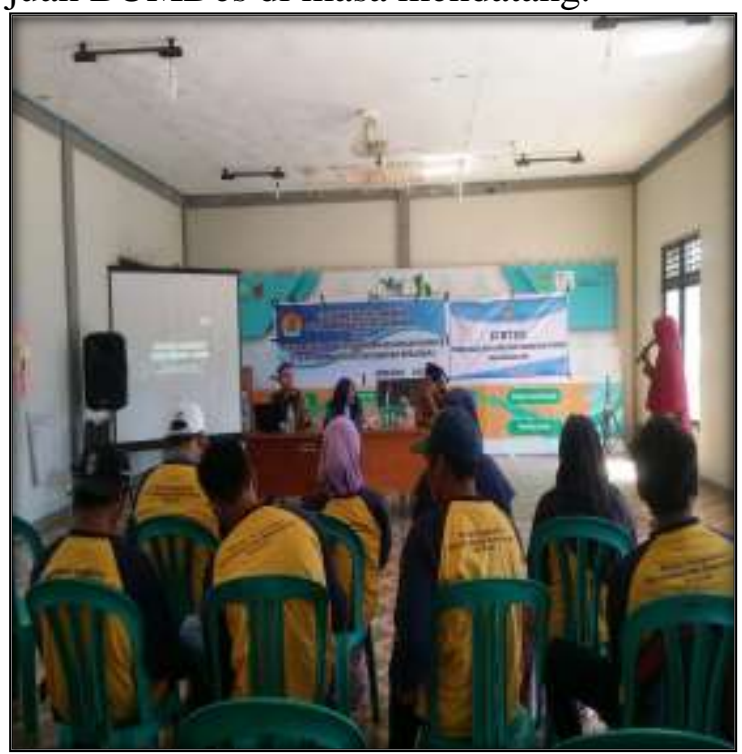

Gambar 3. Kegiatan Seminar Pengelolaan

BUMDes dan Administrasi Pelaporan

Keuangan

2. Kegiatan Pelatihan Penyusunan Laporan Keuangan

Kegiatan pelatihan dilaksanakan sehari setelah pemberian materi "Pengelolaan BUMDes dan Adimistrasi Pelaporan Keuangan BUMDes". Kegiatan ini diadakan 2 (dua) hari, tepatnya pada tanggal 5 s.d 6 Agustus 2019. Adapun peserta yang hadir adalah para pengelola BUMDes. Sebelum kegiatan pelatihan dimulai, tim $\mathrm{PkM}$ memberikan penjelasan mengenai materi pembukuan BUMDes dalam sebuah presentasi yang meliputi:

- Kewajiban dalam melakukan pembukuan.

- Prinsip pembukuan keuangan BUMDes.

- Tujuan dilakukannya pencatatan akuntansi.

- Istilah akuntansi yang umum digunakan dalam pembukuan BUMDes.

- Siklus Akuntansi.

- Standar nama, nomor, dan klasifikasi rekening pada sistem akuntansi BUMDes.

Pelatihan dimulai dengan memberikan contoh-contoh tentang transaksi, bagaimana cara membuat jurnal, cara memposting ke buku besar, cara membuat neraca saldo serta mengajarkan cara membuat laporan keuangan melalui simulasi dari contoh yang umum ditemui di bidang akuntansi. Setelah simulasi dilakukan, kemudian para pengelola diajarkan untuk membukukan transaksi yang riil dilaksanakan pada BUMDes Sedahan Jaya. Proses akuntansi yang dilaksanakan diaplikasikan dengan basis komputerisasi menggunakan MS Office Excel. Dengan adanya kegiatan pelatihan ini diharapkan pengelola BUMDes dapat membukukan setiap transaksinya ke dalam laporan keuangan yang sesuai dengan kaidah akuntansi. Laporan keuangan membantu suatu instansi dalam pengambilan keputusan secara jangka panjang. Pengambilan keputusan inilah yang akan menentukan kondisi ke depan instansi. Begitu pula dengan BUMDes dalam melaporkan kekayaan yang dimiliki membutuhkan laporan 
keuangan untuk mencerminkan kondisinya selama periode tertentu (Irawati \& Martanti, 2017)

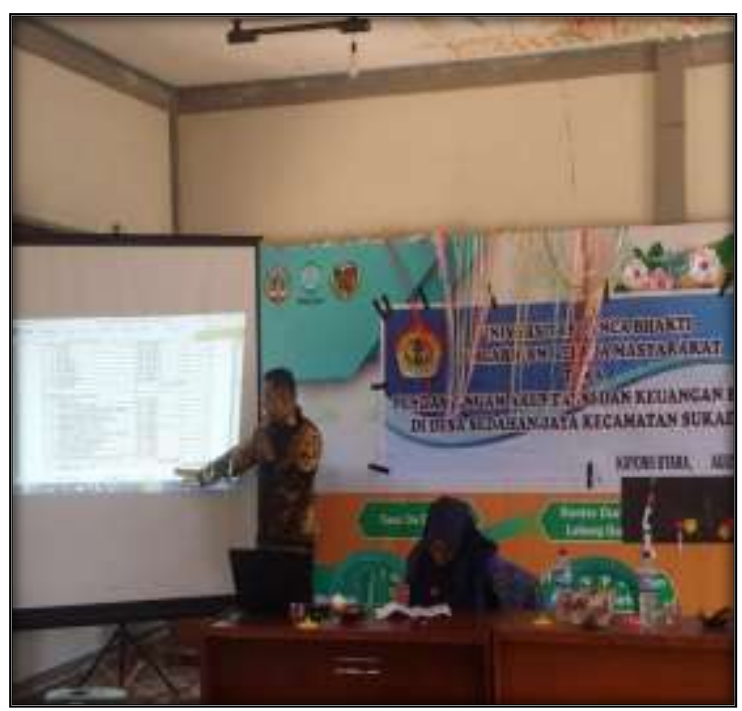

Gambar 4. Kegiatan Pelatihan Penyusunan Laporan Keuangan

\section{Tahap Evaluasi}

Pada tahap ini, aktivitas yang dilakukan adalah dengan mengevaluasi kegiatan yang telah dilaksanakan dengan melakukan pemetaan kelemahan/kekurangan atau kelebihan. Apabila ditemukan adanya kekurangan, maka akan ditindaklanjuti dengan melakukan perbaikan dengan melibatkan para pengelola BUMDes dan juga Kepala Desa.

Selama kegiatan berlangsung baik kegiatan seminar maupun pelatihan, nampak dari para peserta secara aktif mengikuti kegiatan sampai acara selesai. Mereka banyak bertanya dan ingin mengetahui tentang materi yang disampaikan secara mendalam. Akan tetapi dalam proses kegiatan, tim $\mathrm{PkM}$ juga menemui kendala dikarenakan para peserta awam dengan materi yang disajikan dan juga penyebab yang utama karena mereka belum pernah memperoleh pelatihan, sehingga dengan adanya kegiatan ini, pihak pemerintah desa dan pengelola BUMDes sangat terbantukan untuk dapat memahami dan mengetahui tentang pengelolaan BUMDes dan cara membuat laporan keuangan.
Kegiatan $\mathrm{PkM}$ tentang pelatihan penyusunan laporan keuangan telah pernah dilakukan yang menyimpulkan bahwa penyusunan laporan keuangan dengan menggunakan MS Office Excel bertujuan untuk menyajikan informasi keuangan yang berguna bagi institusi serta pihak yang berkepentingan (Yudha, Marlina, \& Fahmi, 2016). Pada bulan Desember tahun 2019, pengelola BUMDes telah membukukan transaksi yang terjadi selama satu periode sebagai berikut:

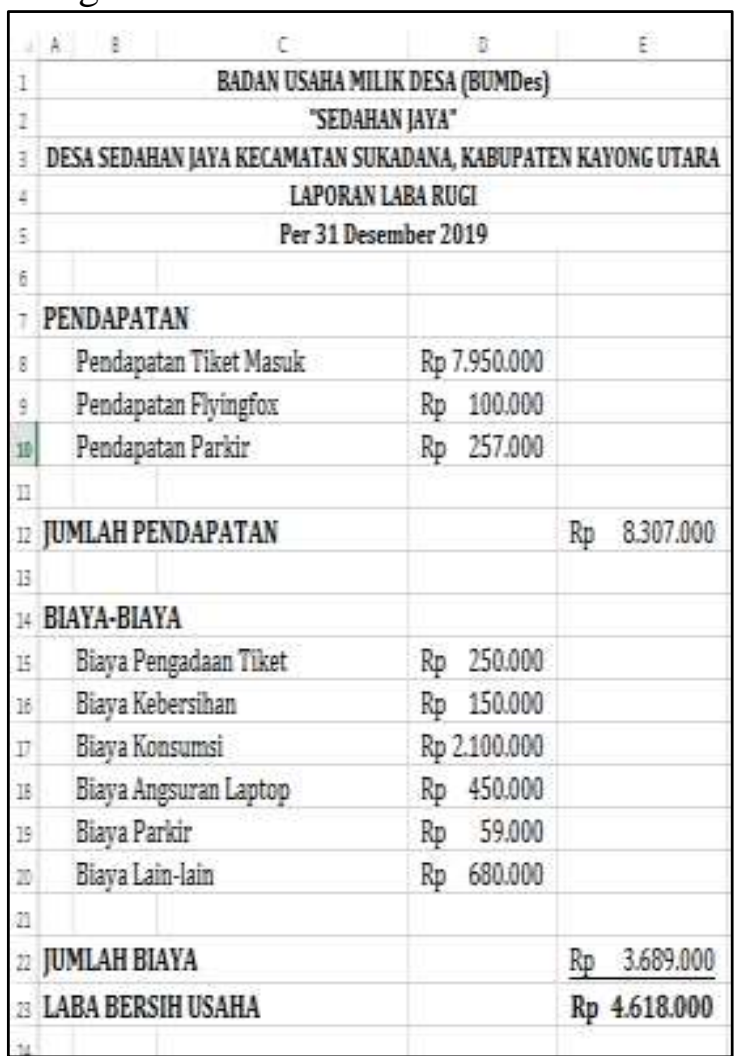

Gambar 5. Contoh Laporan Keuangan BUMDes Sedahan Jaya

Dalam kegiatan PkM ini, ditemukan beberapa kendala di lapangan. Adapun kendala yang dihadapi sebagai berikut:

1. Para peserta masih awam dengan materi yang disampaikan.

2. Para peserta seminar dan pelatihan sulit memahami materi.

3. Penetapan hari dan tanggal pelaksanaan yang harus disesuaikan dengan kondisi dari para peserta.

4. Lokasi PKM yang letaknya jauh dari ibukota provinsi. 
5. Pengelola BUMDes memiliki tingkat pendidikan SMA, bahkan masih ada pengelola yang hanya tamat SMP dan pengelola BUMDes yang menjadi bendahara sama sekali tidak paham dengan akuntansi.

Kendala yang sama juga pernah dihadapai oleh BUMDes Tugu Sari Pajahan, dari hasil penelitian diperoleh bahwa dalam menyusun laporan keuangan sesuai dengan format laporan keuangan manufaktur yaitu terkendala masalah SDM dalam keuangan, tingkat kompetensi, lingkup organisasi kecil dan komponenkomponen dalam format laporan keuangan manufaktur yang kompleks (Dwidiyantini, Sulindawati, \& Sujana, 2017).

Untuk mengatasi kendala diatas maka tim melakukan beberapa upaya diantaranya sebagai berikut:

1. Tim PkM menjelaskan secara berulang-ulang dan memberikan contoh mengenai maksud dan tujuan dari kegiatan serta materi yang disampaikan.

2. Tim PkM menyediakan waktu tambahan untuk melatih bendahara BUMDes dalam menyusun laporan keuangan.

3. Karena lokasinya yang jauh, mengharuskan tim PKM untuk menginap di rumah salah satu warga.

Tim PkM memberikan materi dalam format softcopy tentang proses akuntansi secara rinci kepada bendahara BUMDes untuk dipelajari.

\section{Penutup}

\section{Simpulan}

Adapun simpulan dari kegiatan PkM yang telah dilaksanakan sebagai berikut:

1. Para peserta secara antusias mengikuti kegiatan PkM yang dilaksanakan baik seminar maupun pelatihan.

2. Pengelola BUMDes Sedahan Jaya sangat terbantu dengan adanya kegiatan PkM yang dilaksanakan, mereka memperoleh pengetahuan dan pemahaman dalam menyusun laporan keuangan BUMDes.

3. Dalam kegiatan PkM ini, ditemukan beberapa kendala antara lain: para peserta masih awam dengan materi yang disampaikan, para peserta seminar dan pelatihan sulit memahami materi dan pengelola BUMDes memiliki tingkat pendidikan yang masih rendah dan tidak paham dengan akuntansi.

\section{Saran}

Adapun saran yang dapat dijadikan bahan pertimbangan untuk kedepannya sebgai berikut:

1. Kegiatan pelatihan mengenai penyusunan laporan keuangan secara rutin harus diselenggarakan, dibutuhkan peran serta dari pemerintah dalam mewadahi pelatihan tersebut.

2. Pengetahuan tentang pengelolaan BUMDes dari para pengelola harus terus ditingkatkan untuk kemajuan BUMDes yang dikelola.

3. Perlu adanya keberlanjutan dari program PkM ini untuk tahun berikutnya agar dapat melihat sejauh mana perkembangan dari BUMDes dalam mengelola dan mempertanggungjawabkan keuangan usahanya.

\section{Daftar Pustaka}

Agunggunanto, E. Y., Arianti, F., Kushartono, E. W., \& Darwanto. (2016). Pengembangan Desa Mandiri Melalui Pengelolaan Badan Usaha Milik Desa (BUMDes). Jurnal Dinamika Ekonomi dan Bisnis, 13(1).

Anggraeni, M. R. R. S. (2016). Peranan Badan Usaha Milik Desa (BUMDes) Pada Kesejahteraan Masyarakat Pedesaan (Studi Pada Bumdes Di Gunung Kidul, Yogyakarta). Modus, 28(2), 155-167.

Dwidiyantini, K. A., Sulindawati, N. L. G. E., \& Sujana, E. (2017). Penyusunan 
Laporan Keuangan Manufaktur Pada Badan Usaha Milik Desa (BUMDes) Tugu Sari Pajahan Kecamatan Pupuan Kabupaten Tabanan. Jimat, 7(1).

Hidayat, A. T., Pujiati, L., Hidyati, N., Hendrawan, S. A., Suprapto, S., \& Nurali. (2018). Pendampingan Penyusunan Laporan Keuangan Pada Badan Usaha Milik Desa (Bumdes) Lestari Desa Bandung Kecamatan Diwek Jombang. Comvice, 2(1).

IAI. (2018). Standar Akuntansi Keuangan. Jakarta: Ikatan Akuntan Indonesia.

Irawati, D., \& Martanti, D. E. (2017). Transparansi Pengelolaan Laporan Keuangan BUMDes Terhadap Pelaporan Aset Desa (Studi Fenomenologi pada BUMDes Desa Karangbendo Kec Ponggok Kab Blitar). Paper presented at the Prosiding Seminar Nasional dan Call For Paper Ekonomi dan Bisnis, Jember.

Kusmayadi, D., Firmansyah, I., \& Rahman, R. (2019). IbBM Penyusunan Laporan Keuangan Bumdes dan Koperasi Nelayan di Desa Sancang Kabupaten Garut. Jurnal Pengabdian Siliwangi, 5(1).

Mutiarni, R., Zuhroh, S., \& Utomo, L. P. (2018). Pendampingan Pencatatan Transaksi dan Penyusunan Laporan Keuangan Badan Usaha Milik Desa (Bumdes) Putra Subagyo Desa Miagan - Jombang. Comvice, 2(1).

Norita, Zal, Ridwan, \& Evy. (2018). Sedahan Jaya Siap Menjadi Desa Wisata. Retrieved from http://infopublik.id/read/267116/seda han-jaya-siap-menjadi-desawisata.html

Purnama, S., Iskandar, \& Dirhamsyah, M. (2019). Persepsi Masyarakat Terhadap Potensi Ekowisata di Desa Sedahan Jaya Kecamatan Sukadana Kabupaten Kayong Utara. Hutan Lestari, 7(1), 248-255.
Suwardjono. (2014). Teori Akuntansi Perekayasan Pelaporan Keuangan. Yogyakarta: BPFE.

Yudha, A., Marlina, T., \& Fahmi, A. (2016). Pelatihan Membuat Laporan Keuangan Dengan Microsoft Excel Bumdes Pagelaran. Jurnal Pengabdian Kepada Masyarakat, 1(1).

Zulkarnaen, R. M. (2016). Pengembangan Potensi Ekonomi Desa Melalui Badan Usaha Milik Desa (BUMDes) Pondok Salam Kabupaten Purwakarta. Dharmakarya: Jurnal Aplikasi Ipteks untuk Masyarakat, 5(1), 1-4.

Undang-undang Nomor 6 Tahun 2014 Tentang Desa. 